\title{
DESIGN THINKING APPROACH IN TRANSLATING BANYUMAS TOURISM TEXTS
}

\author{
Nadia Gitya Yulianita, Nisa Roiyasa, Tri Wahyu Setiawan Prasetyoningsih \\ Universitas Jenderal Soedirman, Purwokerto, Indonesia \\ E-mail: nadiagityay@unsoed.ac.id
}

Received: 25 September 2020

Accepted: 05 December 2020

\begin{abstract}
The research aims to identify the students' translation quality in translating Banyumas tourism texts. Moreover, this research tries to find out the effect of design thinking approach in translation class. This research was conducted by applying descriptive qualitative method. In other words, this research describes the effect of design thinking approach to the students' translation by dividing students of English Diploma Study Program, Universitas Jenderal Soedirman enrolling on Translation Indonesian-English class into two classes. Class $A$ uses design thinking approach in translating the texts, while class $B$ does not. The students focus on translating Banyumas tourism texts. After the students translate the texts, the researchers and raters do a focus group discussion to check and rate their translation quality in terms of accuracy. The result shows that the translation quality of class $A$ is better than that of class B. It can be seen from the accuracy point of class $A$ which is 2.95 meanwhile, class $B$ has 2.90 for its accuracy. This proves that design thinking approach is suitable to teach translation.
\end{abstract}

Keywords: design thinking approach, tourism texts, translation class, accuracy.

\section{Introduction}

Creating a lively classroom atmosphere is one of the challenges for teachers. This can be done by implementing an approach to enable students to involve in teaching and learning process. Design thinking is a new approach to learning, collaboration and problem solving. Initially, this approach was applied in business field. It allows wide space for human-centred innovation to grow. This approach involves customers to suit the needs of the targets. Liedtka (2015) states that the customers' needs will lead the company to the new ideas with the best competitive advantage. In other words, design thinking treats the clients' needs and problems as the basis to create new excellent ideas. This approach has similar characteristics with TaskBased Learning. Both focus on how the students are guided to solve problems. Yet TBL only has three stages namely pre-task, task cycle, and post-task (Willis, 1996) while design thinking consists of five stages; emphasizing, defining (the problem), ideating, prototype, and test (Dam \& Teo, 2018). Carroll, M., et al (2010) suggests that design thinking is suitable to be implemented in academic level because it can create critical thinking experience and creativity for students.

There were many researches discussing design thinking for the past few years (Koch, 2016; Leifer, 2016; Sirkin, 2016; Sonalkar, 2016; Wenzel, 2016). However, those researches mainly discussed on the implementation of design thinking in business. They defined design thinking, its implementation, and the advantages. Meanwhile, other researchers discussed the 
implementation of design thinking in education (Kwek, 2011; Razzouk \& Shute, 2012). Kwek (2011) did a research about the implementation of this new learning method in a public middle school in San Francisco Bay Area. He tried to get fuller understanding on the teacher's decisions to adopt this innovative teaching approach. Meanwhile, Razzouk \& Shute (2012) emphasized on the features and characteristics of design thinking and discussed its importance in promoting students' problem-solving skills in the 21st century. As far as we are concerned, we have not found any article discussing mainly on the implementation of design thinking in translation class. Thus, this research is intended to investigate how effective design thinking can be implemented in translation class to create an active teaching and learning process.

On the other hand, the researches about translation, especially researches about translation quality have been conducted by many researchers. Translation quality is usually determined by its accuracy, acceptability, and readability ( Nababan et al., 2012). Santika et al. (2020) discussed the accuracy of commissive response translation, while Yulianita et al. (2018) conducted a research about the acceptability of religious terms. In addition, Nababan et al. (2018) did a research about the readability of translated bible stories for children.

This paper aims to find out the effect of this approach called design thinking in translation class, especially in the translation accuracy. To produce accurate translations, the translator should be able to solve the problems he found during the translation process. This action surely needs a good critical thinking. Therefore, this approach was selected to be conducted in translation class.

The translation class selected for this research is Translation Indonesia-English for General Purposes. This course is offered for the $4^{\text {th }}$ semester students in English Diploma Program, Universitas Jenderal Soedirman. Besides, this research focuses on the Banyumas tourism texts since tourism is the second biggest foreign exchange for Indonesia.

\section{Literature Review}

Teaching approach always undergoes some improvements every time. It is proven by the development of teaching approach found by some experts and educators. Still, some educators apply the traditional teaching approach which is usually called PPP (Present, Practice, Produce). Willis (1996) mentions that this approach involves material presentation from the teacher, exercises done by the students, and self-produced product from the students. However, this approach is considered unsuitable to teach students in the $21^{\text {st }}$ century, since it cannot trigger students' critical thinking. As a matter of fact, the ability to think critically is needed to compete in this globalization era (Pink, 2005). Therefore, taskbased learning is considered more suitable to enhance students' ability to solve some problems (Kwek, 2011).

Task-based learning usually consists of three steps, namely pre-task, task cycle, and posttask. In pre-task stage, the teacher usually introduces the topic and the task. After that, the task cycle stage consists of task, planning, and report. It means that the students start doing their tasks, form the plan on how to report the result of the task, and report it in front of the class. Finally, in the last stage, the teacher let the students listen to their friends' presentations which are already good so that the other students can learn from them (Willis, 1996).

However, task-based learning is also a traditional method which has a weakness if it is implemented in teaching $21^{\text {st }}$ century students. This method still cannot fulfil the needs of the students because they grow up with the development of technology nowadays. Rapid technology development makes the students in this generation demand more skills than the 
previous generations. Some skills that they need are skills and knowledge that are not available at a cheaper price in other countries or that cannot be rendered uselessly by machines, creativity, new skills and knowledge that are needed for living in the global world and the virtual world, high-level cognitive skills, and emotional intelligence (Zhao, 2009). Therefore, design thinking is proposed as a suitable approach to teach young generation.

Design thinking is an approach usually applied in design class or business. This approach consists of some steps based on several references. However, Dam \& Teo (2018) suggests to use five steps of design thinking proposed by Institute Design of Stanford, namely emphasizing, defining (the problem), ideating, prototype, and test. Emphasizing is the step where you understand your client. In translation, it usually deals with the target readers. You have to know your target readers so that you can decide what kind of translation that you produce. Defining is the step where you find the problem(s). You know the problem(s) and try to find a way to solve the problem(s). Ideate is the third step where you start to come up with ideas to solve the problem(s). In the next step, which is prototype, you design the solution(s) of your problem(s). In the last step, test, you expose your solution(s) and get feedback to improve your solution(s).

Since this research emphasizes on the tourism texts, the theory of tourism language is also used. Sulaiman \& Wilson (2019) proposes seven techniques of the language of tourism promotion, namely ego-targeting, keying, contrasting, exoticizing, comparing, poetic devices, and humour. Ego-targeting focuses on the audience or the readers, while keying concentrates on the words used to describe the tourism place attracts the readers. Meanwhile, exoticizing is the use of foreign terms to trigger the readers curiosity. Comparing and contrasting are needed to give comparison or contrast of a place to another so that the readers can get a small description about the tourism place. Poetic devices are applied to give a catchy slogan of a tourism place, and humour is used to add entertaining aspect of the text.

The quality assessment used in this research is the theory proposed by Nababan et al. (2012). They offer three aspects of translation quality assessment, namely accuracy, acceptability, and readability. Accuracy deals with the equivalence of the translation, while acceptability talks about the grammatical and cultural aspects in the target language. Meanwhile, readability determines whether the translation is easy to understand or ambiguous.

\section{Research Method}

This research used descriptive qualitative method. It was done by describing a phenomena the way it was (Kim, 2017). In other words, this research described the effect of design thinking approach to the students' translation. Besides, it is also an embedded case study since the design and main focus of the study had been decided before.

The participants of this research were English Diploma Students Universitas Jenderal Soedirman who enrolled Translation Indonesia-English course. Those students were divided into two classes, namely class A and class B. The lecturers gave four tourism texts to the students and asked them to translate. Class $A$ translated the texts using design thinking approach, while class B students did not use that approach. After that, the researchers conducted a Focus Froup Discussion (FGD) with two raters to assess the translation quality of the students from both classes. The researchers took four samples from students in each class and assess the accuracy of their translations using the translation quality assessment from Nababan et al. (2012). 


\section{Results and Discussion}

The researchers focus on the translation of words and phrases. Thus, several techniques of tourism language found in the four Banyumas tourism texts are ego-targeting, keying, and exoticizing. From those three techniques, keying is the most frequent technique found in those four texts with 73 appearances. In addition, there are 7 ego-targeting and 2 exoticizing found in the texts.

\subsection{Keying}

Keying is the most frequent technique found in the texts because keying deals with keywords used to describe the tourism places. Besides, keying mentions the characteristics of the tourism place to attract the tourists, such as unique, excellent, extraordinary, amazing, and many more (Sulaiman \& Wilson, 2019). The examples of keying technique can be found in the following table.

Table 1. The Accuracy of Keying Technique Translation

\begin{tabular}{|c|c|c|c|c|c|}
\hline \multirow{2}{*}{ No } & \multirow{2}{*}{ Source Language } & \multicolumn{2}{|c|}{ Target Language } & \multicolumn{2}{|c|}{ Accuracy } \\
\hline & & A & B & A & B \\
\hline 1 & $\begin{array}{l}\text { Kota ini pun bisa } \\
\text { terbilang memiliki } \\
\text { wisata yang cukup } \\
\text { lengkap }\end{array}$ & $\begin{array}{l}\text { The city also has } \\
\text { fairly complete } \\
\text { tourism }\end{array}$ & $\begin{array}{l}\text { This town has many } \\
\text { tourist attractions }\end{array}$ & 3 & 2 \\
\hline 2 & $\begin{array}{l}\text { Ruang di bioskop juga } \\
\text { bisa dianggap cukup } \\
\text { luas }\end{array}$ & $\begin{array}{l}\text { The room in the } \\
\text { cinema can also be } \\
\text { considered quite } \\
\text { spacious }\end{array}$ & $\begin{array}{l}\text { Space in the cinema } \\
\text { can also be } \\
\text { considered quite } \\
\text { extensive }\end{array}$ & 3 & 3 \\
\hline 3 & $\begin{array}{l}\text { Harga tiket masuk ini } \\
\text { sangatlah relatif } \\
\text { murah }\end{array}$ & $\begin{array}{ll}\text { The price of } \\
\text { admission } & \text { is } \\
\text { relatively cheap } & \end{array}$ & $\begin{array}{ll}\text { The price of } \\
\text { admission } & \text { is } \\
\text { relative cheap } & \\
\end{array}$ & 2 & 2 \\
\hline 4 & $\begin{array}{l}\text { Di dunia kecil } \\
\text { Purwokerto ini, anda } \\
\text { akan menjumpai } \\
\text { berbagai monumen- } \\
\text { monumen Nasional } \\
\text { yang berada di } \\
\text { seluruh penjuru dunia } \\
\text { ini }\end{array}$ & $\begin{array}{l}\text { In this Small World } \\
\text { Purwokerto, you will } \\
\text { find various } \\
\text { national } \\
\text { monuments located } \\
\text { throughout the } \\
\text { world }\end{array}$ & $\begin{array}{l}\text { In the small world, } \\
\text { you will find } \\
\text { national } \\
\text { monuments in all } \\
\text { the world }\end{array}$ & 3 & 2 \\
\hline
\end{tabular}

The first example shows that student A's translation is more accurate than student B's. It is because student A chose the most equivalent term for "tempat wisata yang cukup lengkap", which is "fairly complete". This translation is the closest equivalence to "cukup lengkap". On the other hand, student B chose "many" which means "banyak" in Indonesia. Therefore, the accuracy for student $B$ is only 2 because she did not translate the term accurately.

For the second example, the accuracy point for each student is high. Even though the translation is different, those terms have the same meaning. "Iuas" can be translated into "spacious" and "extensive". Besides, the context is still the same when those two different translations are used. 
In the third example, student A and student B got the same score in accuracy. This happened because those two translations did not translate the word "sangat". In fact, that word is the key point of tourism keying technique, so it should be translated into "very".

Student $A$ has higher accuracy point than student B in the fourth example because she translated using the closest equivalence. "berbagai monumen-monumen Nasional yang berada di seluruh penjuru dunia" means some national monuments in the world, so it has the same meaning with student A's translation. On the other hand, student B's translation means all of the national monuments in the world. This shows that student B's translation is less accurate.

\subsection{Ego-targeting}

This technique deals with the target readers. It highlights the pronouns that the texts use to address the readers. This technique is usually realized through direct forms of address (Sulaiman \& Wilson, 2019).

Table 2. The Accuracy of Ego-targeting Technique Translation

\begin{tabular}{|c|c|c|c|c|c|}
\hline \multirow[t]{2}{*}{ No } & \multirow[t]{2}{*}{ Source Language } & \multicolumn{2}{|c|}{ Target Language } & \multicolumn{2}{|c|}{ Accuracy } \\
\hline & & $A$ & $B$ & $A$ & $B$ \\
\hline 1 & $\begin{array}{l}\text { Sudahkan anda } \\
\text { merencanakan } \\
\text { destinasi berlibur? }\end{array}$ & $\begin{array}{l}\text { Have you planned a } \\
\text { vacation } \\
\text { destination? }\end{array}$ & $\begin{array}{l}\text { Have you planned } \\
\text { where to go for your } \\
\text { vacation yet? }\end{array}$ & 3 & 3 \\
\hline 2 & $\begin{array}{l}\text { Bahkan warga dari } \\
\text { luar kota } \\
\text { mengunjungi } \\
\text { Purwokerto hanya } \\
\text { untuk menonton } \\
\text { film di sini }\end{array}$ & $\begin{array}{l}\text { Even residents } \\
\text { from out of town } \\
\text { visit Purwokerto } \\
\text { just to watch film } \\
\text { here. }\end{array}$ & $\begin{array}{l}\text { Even residents from } \\
\text { out of town visit } \\
\text { Purwokerto just to } \\
\text { watch a film here. }\end{array}$ & 3 & 3 \\
\hline 3 & $\begin{array}{l}\text { Objek yang dikelola } \\
\text { oleh Pemerintah } \\
\text { Kabupaten } \\
\text { Kebumen ini juga } \\
\text { memiliki taman } \\
\text { bunga sebagai isi } \\
\text { Kebun } \quad \text { Raya } \\
\text { Baturaden } 2016 \\
\text { yang sangat } \\
\text { terkenaldikalangan } \\
\text { para wisatawan } \\
\text { karena } \\
\text { keindahannya. }\end{array}$ & $\begin{array}{l}\text { The object } \\
\text { managed by the } \\
\text { Kebumen Regency } \\
\text { Government also } \\
\text { has a flower garden } \\
\text { as the contents of } \\
\text { the } 2016 \\
\text { Baturaden } \\
\text { Botanical Garden } \\
\text { which is very } \\
\text { popular among } \\
\text { tourists because of } \\
\text { its beauty }\end{array}$ & $\begin{array}{l}\text { The object managed } \\
\text { by the Kebumen } \\
\text { Regency Government } \\
\text { also has a flower } \\
\text { garden as the } \\
\text { contents of the } 2016 \\
\text { Baturaden Botanical } \\
\text { Garden which is very } \\
\text { popular among } \\
\text { tourists because of its } \\
\text { beauty. }\end{array}$ & 3 & 3 \\
\hline 4 & $\begin{array}{l}\text { Berbagai spot } \\
\text { menarik dan indah, } \\
\text { dengan udara yang } \\
\text { sejuk, dan } \\
\text { pemandangan } \\
\text { alam sekitar yang } \\
\text { menakjubkan }\end{array}$ & $\begin{array}{l}\text { Various interesting } \\
\text { and beautiful spots, } \\
\text { with cool air, and } \\
\text { amazing } \\
\text { surrounding } \\
\text { natural scenery } \\
\text { make this Small }\end{array}$ & $\begin{array}{l}\text { Interesting spots and } \\
\text { beautiful, with the } \\
\text { cool air, and the } \\
\text { wonderful nature of } \\
\text { the surroundings } \\
\text { makes this small world } \\
\text { Purwokerto more }\end{array}$ & 3 & 2 \\
\hline
\end{tabular}




\begin{tabular}{|l|l|l|l|l|l|}
\hline membuat Small & World Purwokerto & beautiful and that & & \\
World Purwokerto & more beautiful and \\
must be visited & & \\
ini menjadi lebih & you really must & & \\
indah dan wajib & visit. & & \\
banget kamu & & & \\
kunjungi & & & \\
\hline
\end{tabular}

The translations from both students in the first, second, and third example are the same. Therefore, the accuracy point for each example is also the same. However, in the last example, student A translated the word "kamu", while student B did not. This makes the translation of student $B$ is less accurate than student $A$ 's.

\subsection{Exoticizing}

Exoticizing is the use of foreign word that the readers have little knowledge of. This technique is expected to raise curiosity in readers' mind about that particular word, so that they will come and witness it by themselves. Besides, it can also give the authenticity of the place.

Table 1. The Accuracy of Exoticizing Technique Translation

\begin{tabular}{|c|c|c|c|c|c|}
\hline \multirow[t]{2}{*}{ No } & \multirow[t]{2}{*}{ Source Language } & \multicolumn{2}{|c|}{ Target Language } & \multicolumn{2}{|c|}{ Accuracy } \\
\hline & & A & B & A & B \\
\hline 1 & $\begin{array}{lr}\text { Small World } \\
\text { Purwokerto adalah } \\
\text { sebuah tempat } \\
\text { wisata di kota } \\
\text { Purwokerto. }\end{array}$ & $\begin{array}{l}\text { Small World } \\
\text { Purwokerto is a } \\
\text { tourist attraction in } \\
\text { the city of } \\
\text { Purwokerto. }\end{array}$ & $\begin{array}{l}\text { Small world } \\
\text { purwokerto is a tour } \\
\text { site in the purwokerto } \\
\text { city. }\end{array}$ & 3 & 3 \\
\hline 2 & 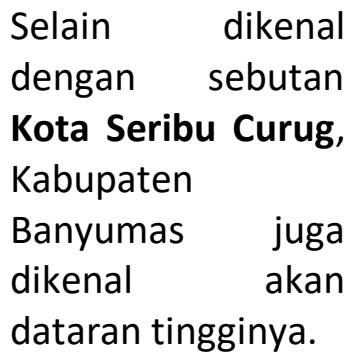 & $\begin{array}{l}\text { Besides being } \\
\text { known as the City } \\
\text { of a Thousand } \\
\text { Curug, Banyumas } \\
\text { Regency is also } \\
\text { known for its } \\
\text { plateau. }\end{array}$ & $\begin{array}{l}\text { Besides being known } \\
\text { as the City of } \\
\text { Thousand Curug, } \\
\text { Banyumas Regency is } \\
\text { also known for its } \\
\text { plateau. }\end{array}$ & 3 & 2 \\
\hline
\end{tabular}

Exoticizing in the first example lies in the phrase "Small World". It is the name of that tourism place that exhibits national monument miniatures from around the world. The accuracy point for both translations is high because the students keep the foreign term to make the readers curious. Thus, the readers would like to visit the place.

In the second example, the word "curug" is the indicator of exoticizing. The word "curug" means waterfall. Student A has higher point in accuracy because she translated "kota seribu curug" into "the city of a thousand curug". In other words, she maintained the foreign word "curug" in the target text. Meanwhile, student B translated the term into "the city of thousand curug", which means "kota ribuan curug". The meaning is slightly different in student B's translation. Therefore, it is less accurate.

\section{Conclusion}

In a nutshell, design thinking approach is suitable to be implemented in translation class since it makes the accuracy point high. This could be seen from the accuracy point in class $A$ 
which has higher score than class $B$ because class $A$ used design thinking to translate Banyumas tourism texts. Thus, design thinking approach helps the translator find the accurate translation of tourism language.

Nevertheless, the result of this research can be developed more. For translators, the result of this research can give insights on how to use design thinking approach to translate. In addition, this approach can help translation teachers to teach translation. Moreover, future researchers can conduct similar research with different population or subject to discover the suitability of design thinking approach in other fields.

\section{ACKNOWLEDGEMENTS}

We would like to express our gratitude to LPPM Universitas Jenderal Soedirman (Institution of Research and Community Service) for fully funded this research under the scheme Riset Dosen Pemula fiscal year 2020, Grant No. Kept. 122/UN23.18/PT.01.05/2020 with the proposal entitled "Design Thinking dalam Kelas Penerjemahan dan Dampaknya terhadap Terjemahan Mahasiswa Bahasa Inggris Universitas Jenderal Soedirman"

\section{References}

Carroll, M., Goldman, S., Britos, L., Koh, J., Royalty, A., \& Hornstein, M. (2010). Destination, Imagination and the Fires Within: Design Thinking in a Middle School Classroom. International Journal of Art \& Design Education, 29(1), 3753.http://www.iimagineservicedesign.com/wp-content/uploads/2015/08/DesignThinking-Concepts-at-School-K-to-12-Article-PDF.pdf.

Dam, R. F., \& Teo, Y. S. (2018). 5 Stages in the Design Thinking Process. https://www.interaction-design.org/literature/article/5-stages-in-the-designthinking-process

Kim, H. (2017). Characteristics of Qualitative Descriptive Studies: A Systematic Review. ResNurs Health, 40(1),

2342.https://www.ncbi.nlm.nih.gov/pmc/articles/PMC5225027/.

Koch, C. (2016). Introduction: The HPI-Stanford Design Thinking Research Program. In L. Plattner, Hasso, Meinel, Christoph, Leifer (Ed.),Design Thinking Research: Making Design Thinking Foundational (pp. 5-12). Springer. https://www.springer.com/gp/book/9783319196404

Kwek, S. H. D. (2011). Innovation in the Classroom: Design Thinking for 21st Century Learning.: StanfordStanford University.

Leifer, L. (2016). Manifesto: Design Thinking Becomes Foundational. In L. Plattner, Hasso, Meinel, Christoph, Leifer (Ed.),Design Thinking Research: Making Design Thinking Foundational (pp. 1-4). Springer. https://www.springer.com/gp/book/9783319196404

Liedtka, J. (2015). Perspective: Linking Design Thinking with Innovation Outcomes through Cognitive Bias Reduction. Journal of Product Innovation Management, 32(6), 925-938. https://doi.org/10.1111/jpim.12163

Nababan, H., Nababan, M., \& Santosa, R. (2018). Translation Techniques and Their Impact on the Readability of Translated Bible Stories for Children. Humanus: Jurnal IImiah IImuIlmu Humaniora, 17(2). https://doi.org/10.24036/humanus.v17i2.102729

Nababan, M., Nuraeni, A., \& Sumardiono. (2012). Pengembangan model penilaian kualitas terjemahan. Kajian Linguistik Dan Sastra, 24(1), 39- 
57.https://publikasiilmiah.ums.ac.id/xmlui/handle/11617/2220.

Pink, D. H. (2005). A Whole New Mind: Why Right-brainers Will Rule the Future. Riverhead.

Razzouk, R., \& Shute, V. (2012). What Is Design Thinking and Why Is It Important? Review of Educational Research, 82(3), 330-348. https://doi.org/10.3102/0034654312457429

Santika, D., Nababan, M., \& Djatmika, D. (2020). The Impact of Translation Techniques on the Accuracy of the Translation of Commissive Speech Acts' Responses in Dark Matter Novel. Humanus, 19(1), 1. https://doi.org/10.24036/humanus.v19i1.102684

Sirkin, D. (2016). Improving Design Thinking Through Collaborative Improvisation. In L. Plattner, Hasso, Meinel, Christoph, Leifer (Ed.), Design Thinking Research Making Design Thinking Foundational (pp. 93-108). Springer. https://www.springer.com/gp/book/9783319196404

Sonalkar, N. (2016). Diagnostics for Design Thinking Teams. In L. Plattner, Hasso, Meinel, Christoph, Leifer (Ed.), Design Thinking Research Making Design Thinking Foundational (pp. 35-51). Springer. https://www.springer.com/gp/book/9783319196404

Sulaiman, Z., \& Wilson, R. (2019). Translation and tourism: Strategies for effective crosscultural promotion. Springer Nature Singapore Pte Ltd.

Wenzel, M. (2016). Globalized Design Thinking: Bridging the Gap Between Analog and Digital for Browser-Based Remote Collaboration. In L. Plattner, Hasso, Meinel, Christoph, Leifer (Ed.), Design Thinking Research Making Design Thinking Foundational (pp. 1533). Springer. https://www.springer.com/gp/book/9783319196404

Willis, J. (1996). A flexible framework for task-based learning An overview of a task-based framework for language teaching.Oxford, Prabhu 1987, 52-62. http://www.intrinsicbooks.co.uk/title_by_title/framework.html

Yulianita, N. G., Nababan, M., \& Djatmika, D. (2018). The Acceptability of Religious Terms Translation in the Complete Idiot's Guide to Understanding Islam. Lingua Cultura, 12(2), 111. https://doi.org/10.21512/lc.v12i2.3999

Zhao, Y. (2009). Catching Up or Leading the Way. ASCD. 